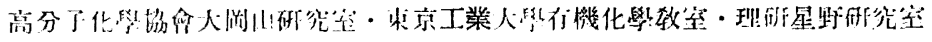

\title{
合成䋐維 の合成㸴究（第21-24献）
}

\section{第 21 報 附加重合辰應の分類に就いて}

岩 '倉義男

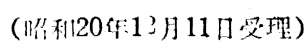

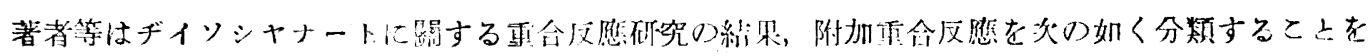
提案する。

附加重合反隹:(Addition polymerisation)

1) 罚立的附加重合(Independent addition polymerisation)

2) 相關的附加重合(Relative addition polymerisation)

a) 相夥的附加重合(Relative addition polymerisation)

b)·柏閵的门已的附加重命(Relative self addition polynierisation)



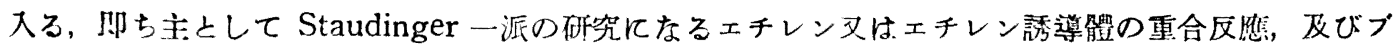

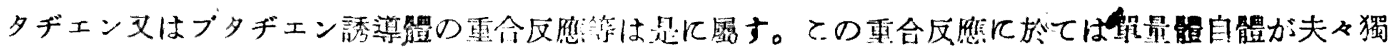

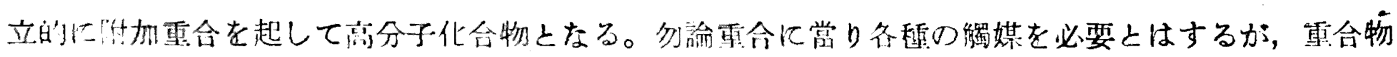

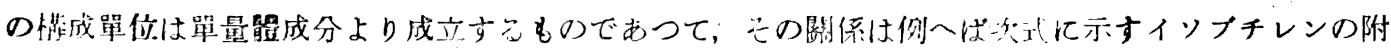
加重合體なるオパノールの場合に於て閳嘹である。

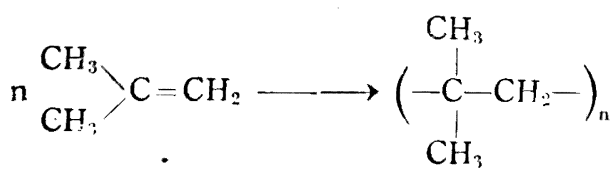

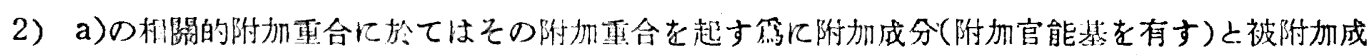

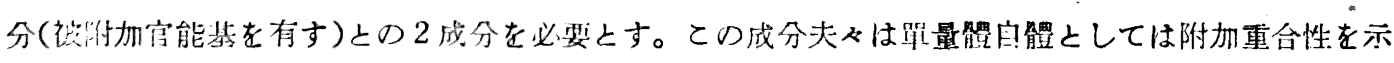
さすして，雨成分の共存する洔，附加官能罯と被附加官能基とが相閔的飞附加反照を示すのである。

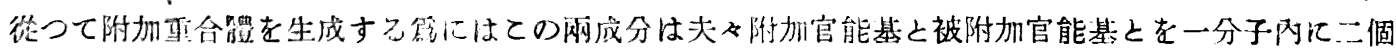
以上有せね将ならぬ。例へばポリウレタン型の附加重合反隼”几於ては附加成分ポリメチレングリコ 一ル(附加官能基一OH基 2 個)之被浙加成分ポリメチレンヂイソシナナート（被附汃官能基一NCO基 2個)とが相躍的に附加反應を行つて車合して行くのである。

$\mathrm{nHO}\left(\mathrm{CH}_{2}\right)_{\mathrm{m}} \mathrm{OH}+\mathrm{nOCN}\left(\mathrm{CH}_{2}\right)_{1} \mathrm{NCO} \longrightarrow\left[-\mathrm{O}\left(\mathrm{CH}_{2}\right)_{\mathrm{m}} \mathrm{OOCNH}\left(\mathrm{CH}_{2}\right)_{1} \mathrm{NHCO}-\right]_{\mathrm{n}}$

上式にて明かの如くてのポリウレタンて於てその篮成單位はポリメチレングリコールとポリメチレ ンチイソシャナートとの附加反應成分よ・り成つものであつて, 上钎1)の猲立的附加重合の場台之明確 に區別せられるへきものである。

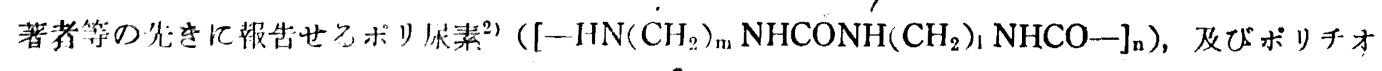


フレタン3) $\left(\left[-\mathrm{S}\left(\mathrm{CH}_{2}\right)_{\mathrm{n}} \mathrm{SOCNH}\left(\mathrm{CH}_{2}\right)_{1} \mathrm{NHCO}-\right]_{\mathrm{n}}\right)$ はポリメチレンヂフミン $\left(\mathrm{H}_{2} \mathrm{~N}\left(\mathrm{CH}_{2}\right)_{\mathrm{m}} \mathrm{NH}_{2}\right)$ 及び ミリメチレンヂメルカプタン $\left(\mathrm{HS}\left(\mathrm{CH}_{2}\right)_{\mathrm{m}} \mathrm{SH}\right)$ をポリメチレンヂイソシヤナート $\left(\mathrm{OCN}\left(\mathrm{CH}_{2}\right)_{0} \mathrm{NCO}\right)$ 三附苏重合せしわて台成したものであつて，その附加臬台反應は全くポリウレタンの場合と同㥞の閣

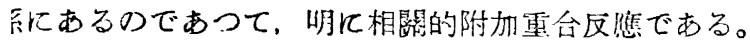

份叉被附加成分としてポリメチレンヂイソチオシヤナート(被附加官能基-NCS 基 2 個)を用ひ，附

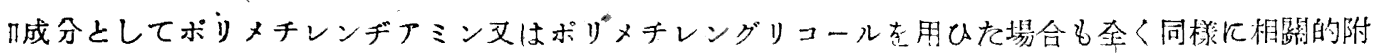

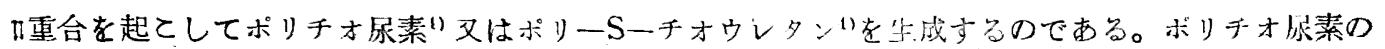
昜台に就々て例示せば次式の如くである。

n $\mathrm{H}_{2} \mathrm{~N}\left(\mathrm{CH}_{2}\right)_{\mathrm{w}} \mathrm{NH}_{2}+\mathrm{n} \mathrm{SCN}\left(\mathrm{CH}_{2}\right)_{1} \mathrm{NCS} \longrightarrow\left[-\mathrm{HN}\left(\mathrm{CH}_{2}\right)_{\mathrm{m}} \mathrm{NHSCNH}\left(\mathrm{CH}_{2}\right)_{1} \mathrm{NHCS}-\right]_{\mathrm{n}}$

ての相關的附加重合反應沉於て被附加成分として更に洘へられるすのにポリメチレンヂケテン $\mathrm{OC}=\mathrm{CH}\left(\mathrm{CH}_{2}\right)_{1} \mathrm{CH}=\mathrm{CO}$ ）(被附加官能基- $\mathrm{CH}=\mathrm{CO}$ 们）があり若しかりる物質を合成し得れば，

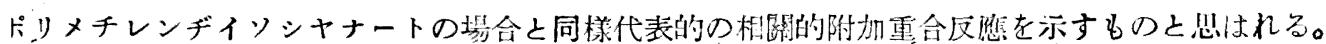

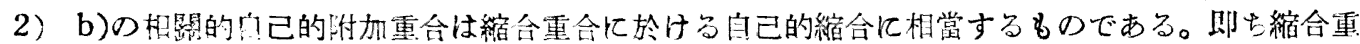

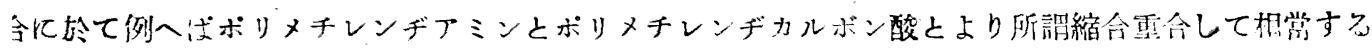

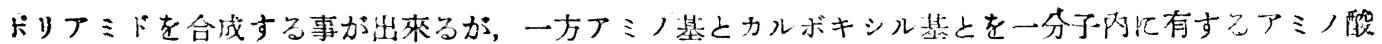

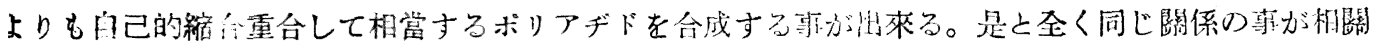
的附加重合》埸台にも位在する。著者等は先きにオキシ酸つヂドを汃熱分解せしめてポリウレタンを

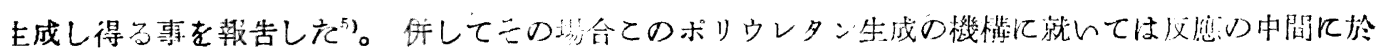
て次式の如くオキシアルキルイソシナナートが生成され次江そのオキシ基とイソシヤナート基とが分 子間に相關的に附加反隹を起こして重台して行くのである之說明した。

$\mathrm{n} \mathrm{HO}\left(\mathrm{CH}_{2}\right)_{\mathrm{m}} \mathrm{CON}_{3} \longrightarrow \mathrm{n} \mathrm{HO}\left(\mathrm{CH}_{2}\right)_{\mathrm{In}} \mathrm{NCO} \longrightarrow\left[-\mathrm{O}\left(\mathrm{CH}_{2}\right)_{\mathrm{m}} \mathrm{NHCO}-\right]_{\mathrm{m}}$

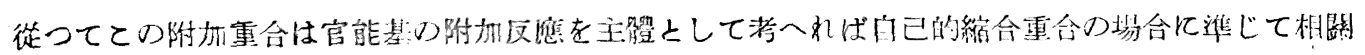
山白已的附加重合と呼程し得ると思ふのである。

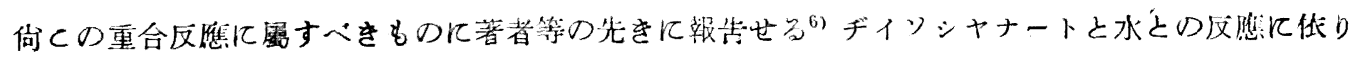

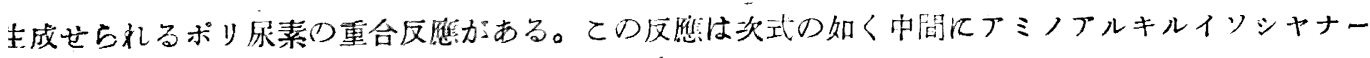

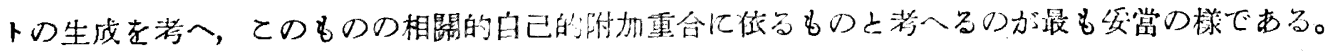

$\mathrm{n} \mathrm{OCN}\left(\mathrm{CH}_{2}\right)_{\mathrm{m}} \mathrm{NCO} \longrightarrow \mathrm{n} \mathrm{H}_{2} \mathrm{~N}\left(\mathrm{CH}_{2}\right)_{\mathrm{m}} \mathrm{NCO} \longrightarrow\left[-\mathrm{NH}\left(\mathrm{CH}_{2}\right)_{\mathrm{n}} \mathrm{NHCO}-\right]_{\mathrm{n}}$

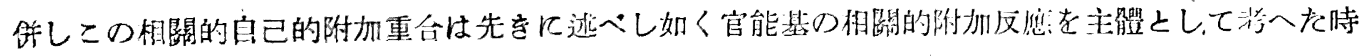

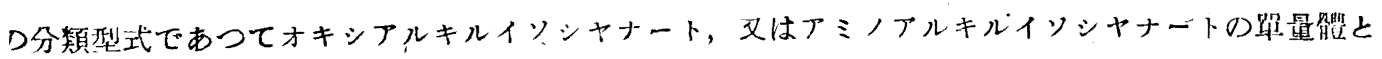
こて重合性及び生成重合顝の櫵成單位等より考へる時は，特殊の場合としてではあるが明かて獨立的

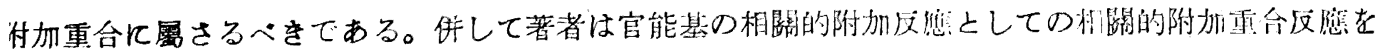

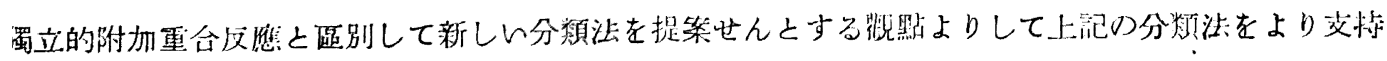
せんとする次第である。






\section{文的}

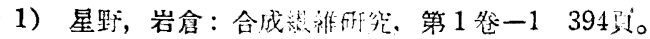

2) 星野, 岩倉：问上, 384頁。

3）星野, 岩含, 石川：闬上, 411 泬。

4）岩倉：同上，427頁。

5）岩倉：间上，第 2 然-?, 1 項。

6) 岩倉：同上, 第 1 参 $-1,4 \% 0$ 宣。

\section{第22報 ホホリデカメチレンオクタメチレンウレタンの合成に就いて}

岩倉 義 男, 岩, 崎 份子

著者等は先にポリメチレングリさコールとポリメチレンヂイソシナナートとの附加重合に依り得られ

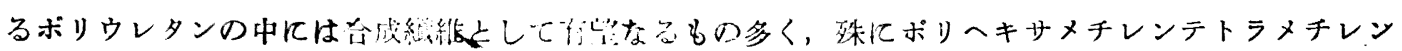

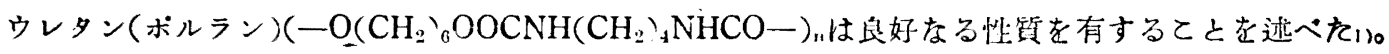

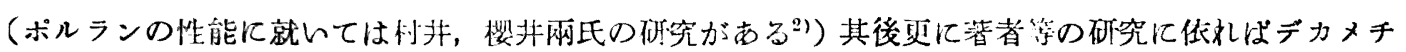
レングリコールとオクタメチレンヂイソシャナートとの附加重合に低り得られるボリデカメチレンオ. クタメチレンウレタンも合成䋱維として良好なる性筫を有する事が刵明した。代してての重合物の製 造原料なるデカメチレングリコール及びオクタメチレンヂイソシナナートは共にセバチン酸より製造

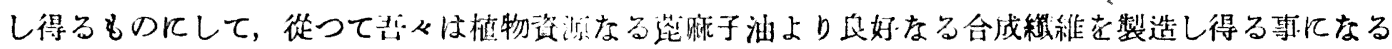
のである。次にその合成經路を间示す。



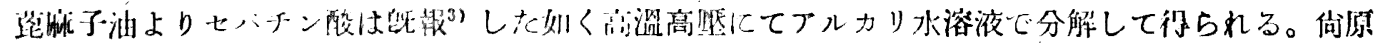

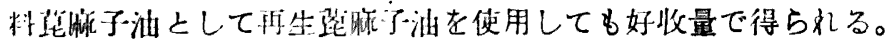

セバチン酸メチルエステルより酸ヒドラヂト，酸フヂドを經てオクタメチレンヂイソシキナートの 合成に關して著者等の最近の合娍法は别に報告しだ。

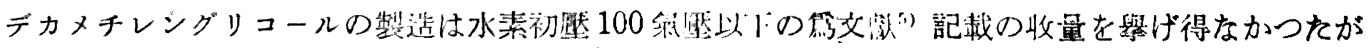
Adkins のJ法にて行ひ，フルカリ分解及びペンシルよりの訬結晶に依り精製した。

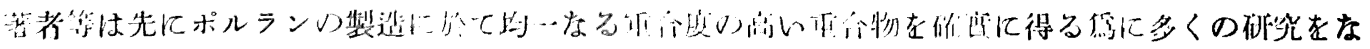

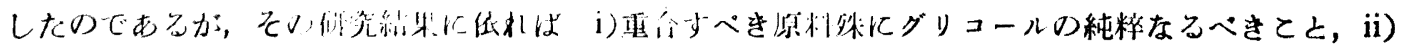

